\title{
Instrument Development to Review Factors for Research Commercialization Study in Universities
}

\author{
Nurshafiza Ismail $^{1, *}$, Nabilla Afzan Abdul Aziz ${ }^{1}$, and Arif Hartono ${ }^{2}$ \\ ${ }^{1}$ Universiti Teknologi PETRONAS, 32610 Seri Iskandar, Perak. \\ ${ }^{2}$ Universitas Islam Indonesia, Daerah Istimewa Yogyakarta 55584, Indonesia.
}

\begin{abstract}
Recently, university commercialization has drawn growing attention to the role of the university as one of the drivers to local economic growth. Majority universities and other research institutes in Malaysia has established Technology Transfer Offices (TTO) to give support and guidance to the researchers in the bid to commercialize Research and Development (R\&D) activities. The issues that are faced by current researchers are progressing and adapting to the role of developing and commercialising products while having lack of business acumen that hinders success in commercialization among the researchers. The objective of this study is to create a research model for commercialization study in universities and developing questionnaire to assess the issue in a holistic view. This study reviews the role of TTO, lists of incentives from the government to the researchers and factors that impedes the researchers' output to the commercial bench. Contextual factor, Process factors and Organizational factors lead to the successful commercialization in the research institutes. A research model for impediment in commercialization is created and questionnaire for TTO and survey for researchers, are developed to investigate on the impediment factors that hinder success in the research commercialization among universities. The in-house developed instruments are modified based on massive literatures on commercialization to stimulate strategies and improvement of units from Planning to Execution role in the TTO. On another hand, researchers in the university will be able to plan and execute their research that will deliver scientific, technological, cultural and economic developments in addressing industrial, culture and social issues.
\end{abstract}

Keywords: Technology Transfer Office (TTO); instrument; research commercialization; impediment; university; incentive government

\footnotetext{
* Corresponding author: nurshafiza.ismail@,utp.edu.my
} 


\section{Introduction}

Commercialization of research products in Malaysia have been recognized as the initiate and acts as a catalyst for economic growth among researchers in universities (Norain et al., 2017). Several studies discovered that the academic setting in this era is not only focused on research and development technology innovation but it involves developing and commercializing products into the marketplaces (N. Ismail et al., 2015).

Moreover, commercialization is a complex process and the challenges faced by the researcher have not been properly addressed. Yu Zhou (2015) stated that many universities have adjusted their policy and opened the door for business purposes activities even though faced several difficulties within the commercialization process due to the nature of universities being academic institution. According to (Power et al., 2005), innovation of technology must be follows to the industrial needs and be relevant to the private sector. There are many technology fails to establish new ventures and most of the technology innovation ended to failure (Ford et al., 2007) to enter the marketplace and achieve continuous growth.

Most universities in Malaysia have technology transfer office (TTO) that are responsible to facilitate the activities of intellectual property protection and activities commercialization before it can be commercialized (Aqilah et al., 2017) such as licensing, patenting, or management of spin-off creations. According to a previous study by Abd Aziz et al. (2010), only a small percentage of technology innovation is successful to be commercialized. Heng et al., (2012) mentioned on the lack of business acumen is the factor that hinders success in commercialization among the researchers. This paper aims to review the factors and to develop a questionnaire to investigate the impediment factors that hinder success in the research commercialization among universities.

\subsection{Malaysian Government Initiative to Support Research Commercialization}

Usually universities in Malaysia has limited funds to run a research project especially project that requires collaboration between University and Industry. The government has strongly emphasized on transformation of the Research and Development (R\&D) to commercial bench, thus the universities are racing to seize the opportunity in order to deliver the aim outlined by the ministry. Support during early stage of the new product or prototype before commercializing is highly required especially by providing several initiatives such as grants and sufficient funds to the researchers.

Universities research has allocated some budget to provide certain support in manpower, practical, circulate information and funding (Sutopo \& Astuti, 2017) for increment in percentage of commercialization from universities. In short, funding is the important to ensure the success in the products commercialization (Khademi \& Ismail, 2013).

Ali et al. (2017) reported on the $10^{\text {th }}$ Malaysian Plan, it was stated that the trend in commercialization rate of Research \& Development products has declined in year 2013 due to several factors that hinders the success during commercialization stage. 
Table 1: $10^{\text {th }}$ Malaysia Plan Ministry of R\&D Schemes for Malaysian Universities (Bakar et al., 2016).

\begin{tabular}{|c|l|c|}
\hline No. & \multicolumn{1}{|c|}{ Scheme } & $\begin{array}{c}\text { Allocation (2011-2012) } \\
\text { RM }\end{array}$ \\
\hline 1 & Fundamental Research Grant Scheme (FRGS) & 300 million \\
\hline 2 & $\begin{array}{l}\text { a. Exploratory Research Grant Scheme (ERGS) } \\
\text { b. Long-Term Research Grant Scheme (LRGS) } \\
\text { c. Prototype Research Grant Scheme (PRGS) }\end{array}$ & 300 million \\
\hline 3 & Research Incentive & 41 million \\
\hline 4 & MOHE Special Project & 100 million \\
\hline & \multicolumn{1}{|c|}{ TOTAL } & 741 million \\
\hline
\end{tabular}

Source: Ministry Of Higher Education website

The government in Malaysia has allocated several funds to the researchers among the universities. Table 2 shows the financial support for the research commercialization to the universities to run their research project that driven to the economic growth.
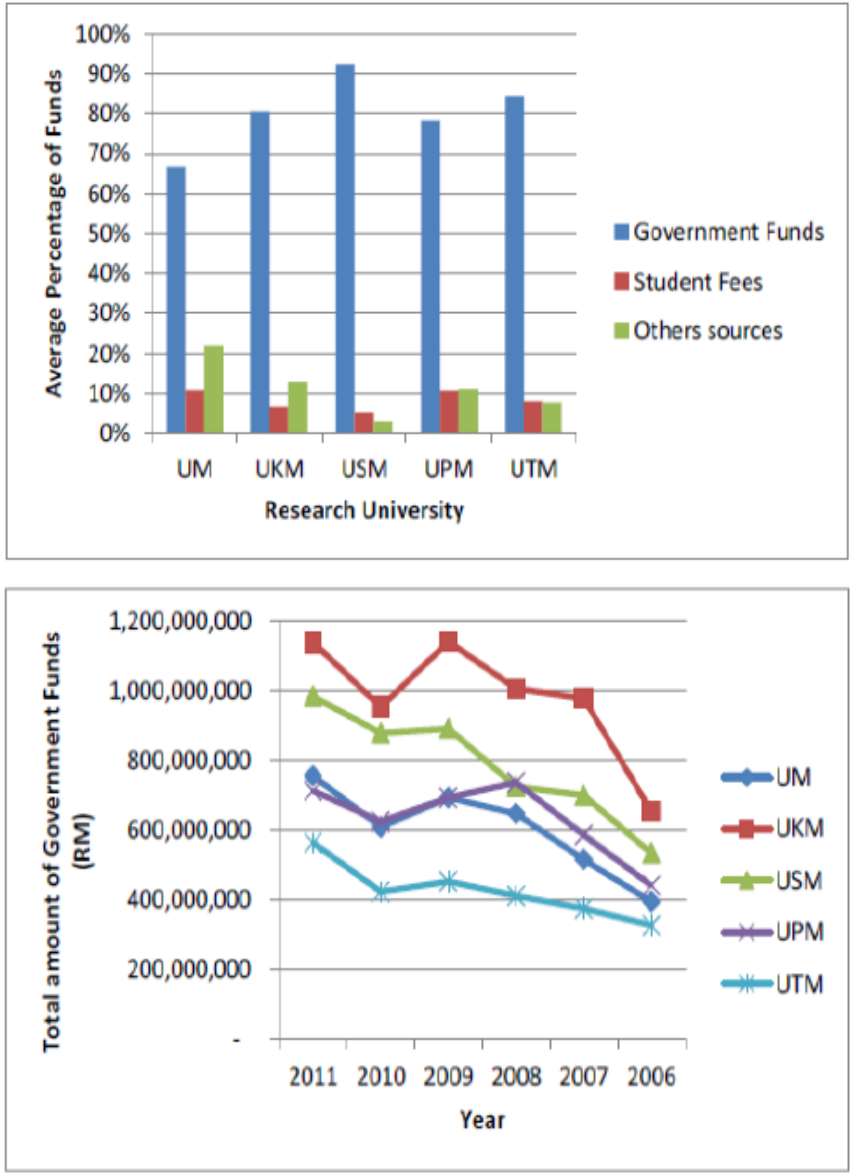

Figure 1: The average percentage of funds and the total amount of government funds received by the Research University (“Abdullahu et al.”, 2017). 
Figure 1 indicate the fund allocation given by Malaysian government has increased for research purposes in universities and this findings strongly supported by (K. Ismail \& Ajagbe, 2013) which is the funding give improvement to the R\&D activities.

Table 2: Financial support from government for research commercialization ("K. Ismail \& Ajagbe",2013)

\begin{tabular}{|c|c|c|}
\hline Ministry & Department & Research Area \\
\hline \multirow[t]{6}{*}{$\begin{array}{l}\text { Ministry of Science, Technology and } \\
\text { Innovation }\end{array}$} & MOSTI & $\begin{array}{l}\text { Research and pre-commercialize } \\
\text { activities for all research types. }\end{array}$ \\
\hline & MIMOS & $\begin{array}{l}\text { Research and pre-commercialize } \\
\text { activities for ICT clusters. }\end{array}$ \\
\hline & MDEC & $\begin{array}{l}\text { Research and pre-commercialize } \\
\text { activities for ICT clusters. }\end{array}$ \\
\hline & MTDC & $\begin{array}{l}\text { Research and pre-commercialize } \\
\text { activities for ICT clusters. }\end{array}$ \\
\hline & Biotech Corp. & $\begin{array}{l}\text { Research and pre-comm. } \\
\text { activities for biotechnology } \\
\text { cluster }\end{array}$ \\
\hline & MAVCAP & $\begin{array}{l}\text { All relevant technology. } \\
\text { All technology sectors. }\end{array}$ \\
\hline $\begin{array}{l}\text { Ministry of International Trade and } \\
\text { Industry }\end{array}$ & $\begin{array}{l}\text { Malaysia External Trade Development } \\
\text { (MATRADE) } \\
\text { Malaysia Industrial Development } \\
\text { Finance (MIDF) } \\
\text { SME Bank (BPMM). } \\
\text { Central Bank Malaysia }\end{array}$ & $\begin{array}{l}\text { Enhance branding and market } \\
\text { exploration capabilities of local } \\
\text { products. } \\
\text { Provision of soft loans to the } \\
\text { industries }\end{array}$ \\
\hline \multirow[t]{4}{*}{ Ministry of Education (MOE) } & $\begin{array}{l}\text { Exploratory Research Grant Scheme } \\
\text { (ERGS) }\end{array}$ & \\
\hline & $\begin{array}{l}\text { Fundamental Research Grant Scheme } \\
\text { (FRGS) }\end{array}$ & $\begin{array}{l}\text { Basic research } \\
\text { Applied R\&D }\end{array}$ \\
\hline & $\begin{array}{l}\text { Long Term Research Grant Scheme } \\
\text { (LRGS) }\end{array}$ & \\
\hline & $\begin{array}{l}\text { Prototype Development Grant Scheme } \\
\text { (PRGS) }\end{array}$ & \\
\hline Ministry of Health (MOH) & $\begin{array}{l}\text { Ministry of Health (MOH) Research } \\
\text { Grant }\end{array}$ & Applied R\&D \\
\hline
\end{tabular}

Source: Yayasan Inovasi Malaysia (Malaysia Innovation Foundation)

Through the provision of an appropriate legislative framework for innovative research culture, and property rights between academics and research institutes, the government plays a vital role in the commercialization of intellectual property. According to some academics, governmental financing accounts for $80 \%$ of research funding in Malaysia (Sharif et al., 2018). 


\subsection{Role of University Institution in Research Commercialization}

In the growth of the knowledge-based economy, universities plays a vital role as facilitators, such as leaders of regional economic and social advancement and innovation systems (Gunasekara, 2004). The academician, according to Charles (2003), is a significant player in the process of the endogenous or locally based Role of universities:

- Clear evidence of a desire for universities to become more entrepreneurial.

- Some universities are more entrepreneurial than others.

- Establishment of research universities.

- Research universities require additional definition.

To support activities and give solutions in commercialization, many institutions have established technology transfer offices (TTOs). TTO is in charge of overseeing technical developments from their inception to the coordination of many parts of technology transfer efforts (Sanberg et al., 2014). TTOs often plays crucial roles in the academic entrepreneurship process in commercialization activities (Wood, 2011). According to the Bayd-Dole Act in 1980, TTO administered intellectual property licences and obligations to promote faculty members for commercialization, such as patent protection and seeking possible university-industry collaborators (Manap A, 2017).
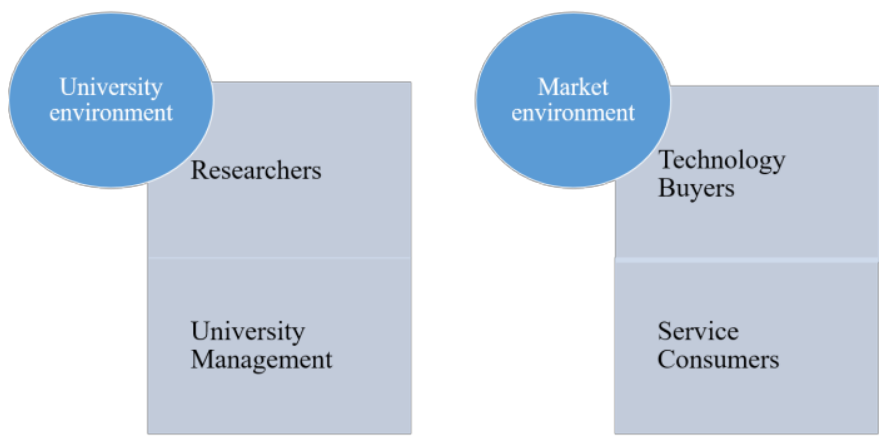

Figure 2: Environment of university technology transfer offices in University ("Juan Jesus Arenas, n.d)

Thursby et al., (2001) found a strong link between the existence of TTO and the growth of university patents such as invention, motivation, and experience (Dai. Y et al., 2007). Due to a shortage of money, government incentives for researchers, expertise workforce, and the ability of academia to commercialise their goods, TTO encountered various hurdles and difficulties in facilitating intellectual property (IP) commercialization in the university (Manap. A et al., 2017).

Increased research funding opportunities, access to unrestricted funds for further institutional investment, maintaining high postgraduate scholarship levels, promoting postgraduate student success, increased prestige, public benefit, and economic development are all advantages of technology transfer. 


\subsection{Literature Review}

The success of research commercialization depends on collaboration amongst a variety of stakeholders with differing perspectives and goals, including government, academia, business, and the fellowship (Markman et al., 2008). Commercialization also has an impact on academia, industry, and government. The Bayh-Dole Act (Ibata-Arens, 2008) made significant modifications to the commercialization framework through legislative reforms. In the United States, the Bayh-Dole Act was enacted to create a patent policy that would encourage patent holders to work with the private sector. As a result, the intellectual property rights of ideas obtained through federal support are shared with the inventor in order to prioritise small businesses in the licencing of commercialization rights. Bayh-Dole targeted primarily federally financed research institutes and, to a lesser extent, universities.

Fletcher and Bourne (2012) emphasised the presence of complicated concerns surrounding how much potential value is locked up in these intellectual assets and how they can best be utilised while being true to the progenitors' aspirations and creating value. There are numerous routes from the laboratory bench to the store: commercialization is part art, part science, part inspiration, and part perspiration, just like any other business process (Fletcher and Bourne, 2012).

\subsection{Impediments to research commercialization}

There are various challenges that have been widely highlighted as impeding success in Malaysian manufacturing and service businesses innovation efforts. The most significant impediments to university-based innovation in the manufacturing and service industries are high costs, a lack of funds inside the organisation, and an unclear demand for goods and services (Ajagbe et al., 2015). Impediments to innovation have a significant influence in shaping the characteristics of a companys innovation environment (Iammarino et al., 2007).

There are numerous impediments in the commercialization process, one of which is a funding impediment, which refers to insufficient financial help for spin-off firms to commercialise academic research outputs. It is true that obtaining financial support for academic commercialisation is difficult. Another hindrance is competency, which refers to the lack of necessary business and technical skills for the commercialization of academic research outputs by both entrepreneurs and academic staff (Azman et al., 2019).

Table 3: List of barriers involved in innovation activities.

\begin{tabular}{|c|c|c|}
\hline Factors & Barriers & References \\
\hline \multirow{4}{*}{ Cost factors } & Too much money is spent on innovation & \multirow{9}{*}{$\begin{array}{c}\text { (Ajagbe et al., 2015; } \\
\text { Dasgupta et al., 2011; } \\
\text { Ee Shiang \& Nagaraj, } \\
\text { 2011; Hartono \& } \\
\text { Kusumawardhani, } \\
\text { 2019; K. Ismail \& } \\
\text { Ajagbe, 2013) }\end{array}$} \\
\hline & Economic risks that are overestimated & \\
\hline & A scarcity of suitable funding sources & \\
\hline & Lack of funds from outside source & \\
\hline \multirow{2}{*}{$\begin{array}{l}\text { Regulatory } \\
\text { factors/public policy }\end{array}$} & $\begin{array}{l}\text { Insufficient flexibility of regulations and } \\
\text { standards }\end{array}$ & \\
\hline & $\begin{array}{l}\text { Limitation of science and technology public } \\
\text { policies }\end{array}$ & \\
\hline \multirow{3}{*}{ Market factors } & $\begin{array}{l}\text { A well-established company dominates the } \\
\text { market }\end{array}$ & \\
\hline & $\begin{array}{l}\text { Demand for innovative goods and services is } \\
\text { uncertain }\end{array}$ & \\
\hline & $\begin{array}{l}\text { Inability of customers to respond to new } \\
\text { products }\end{array}$ & \\
\hline
\end{tabular}




\begin{tabular}{|l|l|}
\hline \multirow{5}{*}{ Knowledge factors } & Lack of information on market \\
\cline { 2 - 2 } & Lack of qualified workers \\
\cline { 2 - 2 } & Lack of information on technology \\
\cline { 2 - 2 } Organisational factors & $\begin{array}{l}\text { Weakness of intellectual property (IP) } \\
\text { knowledge and rights }\end{array}$ \\
\cline { 2 - 2 } & $\begin{array}{l}\text { Difficulties in finding appropriate right } \\
\text { partner collaboration }\end{array}$ \\
\hline & Lack of infrastructure (Eg: building) \\
\cline { 2 - 3 } & $\begin{array}{l}\text { Lack of facilities (Eg: equipment, machine) } \\
\text { (SIRIM,FRIM, universities) }\end{array}$ \\
\hline & Attitude of personnel towards change \\
\cline { 2 - 3 } & Attitude of managers toward change \\
\cline { 2 - 3 } & Organizational rigidities within the enterprise \\
\hline
\end{tabular}

\subsection{Impediment factor related to manpower.}

Universiti Malaya (UM) has developed an effective system to manage their R\&D, monetize their results, and make activities to improve current research facilities and infrastructure (MASTIC, 2008). According to certain studies, universities with effective researchers have a greater chance of increasing the number and quality of research discoveries (Banal-Estanol et al., 2011).

Inadequately skilled workers are the source of the majority of research challenges in academia (Ismail Kamariah, 2012). Skilled labor with relevant professional skills is important in the economic development and growth. Rapidly growing sectors are frequently impeded by a scarcity of skilled workers. Figure 3 shows organizational structure for the majority R\&D manpower research institutes in Malaysia.

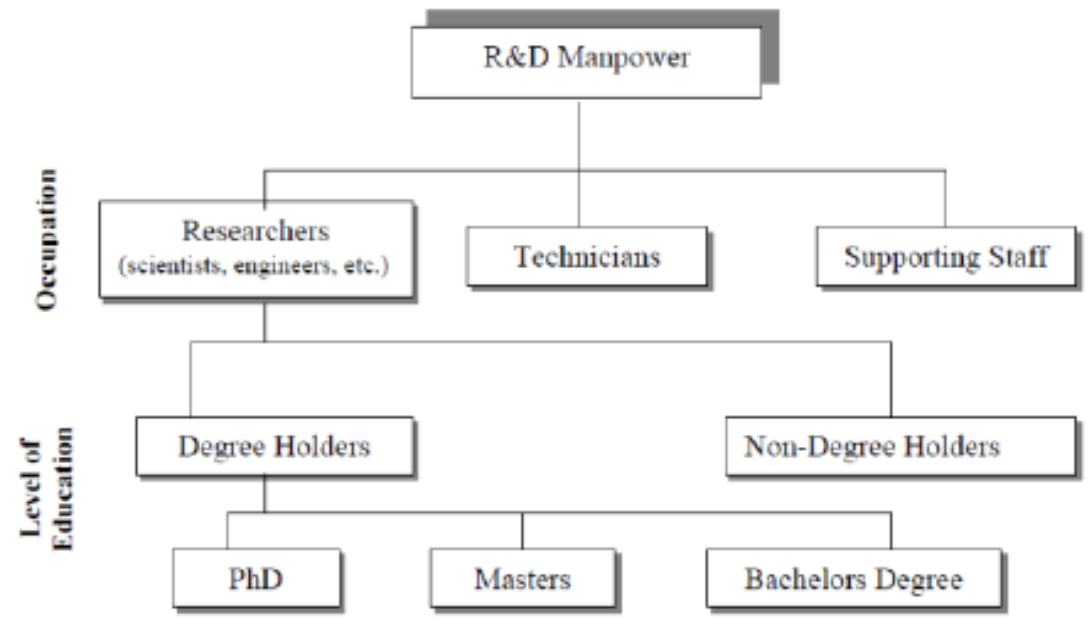

Figure 3: R\&D manpower in Malaysia ("Faizal Ret et al.", nd).

The lack of qualified staff, insufficient practices within workers for technology management and inadequate experience of the people involved results in the low efficiency of commercialization management structures systems. 
In research firms, strategic professionals are expected to have abilities related to spotting possibilities, creating competitive advantages, optimising resources, managing inventor conflicts, adjusting changes, and being more innovative (Stumps and Mullen, 1991). To support this statement, (Boal and Hooijberg, 2000) a leader should be able to make tactical decisions (Abdul Razak \& Murray, 2017), communicate vision and goals, coordinate critical abilities, and establish business culture.

Thus, universities are beginning to emphasise the need for academics with strategic leadership abilities who can have a positive impact on research cultures (Collier et al., 2011; Abdul Razak \& Murray, 2017). In universities, strategic leadership has a significant and favourable relationship with effective innovation and collaborative research (Jewels et al., 2011).

\subsection{Impediment factor related to the marketing strategy.}

The commercialization of patents in universities will be successful if you have a thorough understanding of marketing and management systems. Involvement of inventors in marketing initiatives increases the likelihood of patents being commercialised (Ismail Kamariah, 2012). When new inventions hit the market, the likelihood of obtaining a licence increases (Markman et al., 2005). In the university, many market strategies for research commercialization existed. Internal, quasi-internal, and external approaches were chosen by several institutions (Ismail Kamariah, 2012). Novel IP with commercial potential and funding assistance can be used to identify these tactics and increase their chances of success.

Booz Allen Hamilton (1982) has categorized projects improvement to existing products in six types:

- Improvements to existing items

- New product categories

- New product lines are being added to existing product lines

- New to the market products

- Cost-cutting- process development

- Repositioning-product enhancement

What is unique for one firm is differentiated by the terms "new to the firm," "new to the market," and "new to the world." The four-stage model, which is important for distinguishing between distinct components, must be managed at various phases, as shown below:

- Concept of idea generation

- $\quad$ Project preference

- Product advancement

- Commercialization and review of the product

Some researchers are having trouble coming up with new study ideas. They are faced with the difficult task of producing a product with both commercial and market worth. Thus, academic researchers must have a commercial value in addition to generating products with distinctive attributes. They need to discover a way to make their product stand out in order to become a marketable product. In comparison to existing products on the market, researchers should develop a product that is of high quality, useful, and affordable in order to secure industry partnership (Ismail. $\mathrm{N}$ et al, 2018). 


\subsection{Other Factors that could enhance research commercialization.}

Both the entity institution and the industry should seek effective strategies to overcome barriers in the collaboration through R\&D collaboration in order to acquire more benefits from the contract (Lee et al., 2010). Contextual variables, organisational factors (MoraValentin et al., 2004), and process factors are two important aspects that might contribute to successful R\&D collaboration (Thune, 2011).

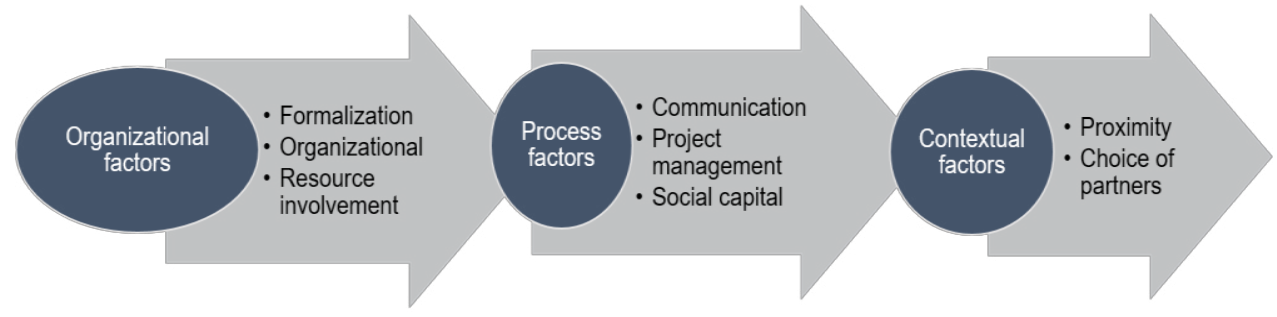

Figure 4: Factors that contribute to the success between university-industry collaboration

(“Thune".2011).

Other factors that had been studied from previous research that drive towards the success of a technology innovation in a research institutes are (Nor \& Jailani, 2014):

i. the researcher

ii. the technology or product

iii. business collaboration

iv. strategic commercialization

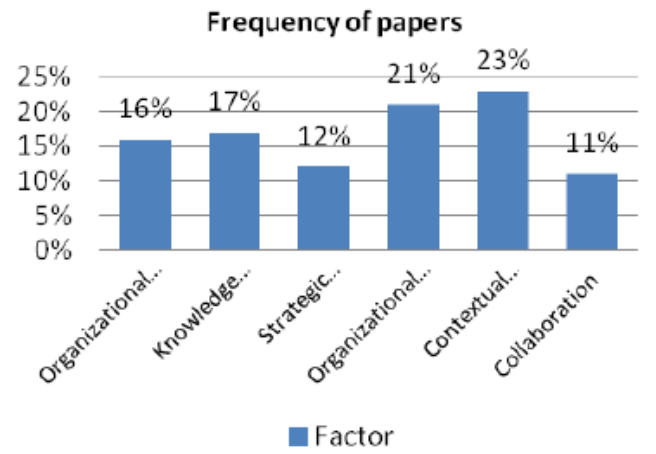

Figure 5: Percentage of successful factors in commercialization ("Abdul Hamid \& Abd. Rahman", 2014).

The percentage of factors gathered from previous studies related to research commercialization is displayed in Figure 5. The contextual factor $(23 \%)$ has the highest value for successful commercialization, indicating that the environment plays a crucial part in determining whether or not an idea has market potential. Organizational support (21\%) is a critical factor for businesses to increase their market innovation, and this variable has been evaluated numerous times. Information on technology, top management support, and a structured patenting system are examples of organisational assistance that improve commercialization performance in order to boost participation in innovation (Datta et al., 
2011). Harmancioglu et al. (2010) mentioned that marketing, learning, and training, new product development potential and organizational innovativeness should give a good attention in future activities.

The impact of networking on invention commercialization performance contributes $12 \%$ to the strategic orientation component. It has been demonstrated that strong relationships with industry participants are necessary for innovation success. Scientists must enlist the help of investors who are on the same page as them and who can explain and advise them. Businesses, on the other hand, must be able to assess what research universities have to offer and how it might benefit the community (Fletcher and Bourne, 2012).

Top management is significant to the new process of development and technology strategy (Sohail, 1997). Leaders are in charge of motivating, facilitating, monitoring, and guiding others, and they have a lot of authority and influence (Kamariah, 2012). As a result, the majority of top management firms in Malaysia are respected for their positions, and they are allowed to use their authority and run the company in the manner that they desire.

Other factors that can lead to increasing in product commercialization innovation is by reducing the gap between university and industry with financially support the university and academics. Industries could propose specific forms of study from universities, and they may have rights to the research's output, or industry and university may agree on the research and its benefits equally (Ismail. $\mathrm{N}$ et al, 2018).

\subsection{Methodology}

This study analyses five factors that influence the research commercialization in universities to develop an instrument for research commercialisation study. The instruments were designed based on literature reviews and to suit with the environment of the academic institution.

There are five sections designed in the survey for the researchers:

i. Impediments to research commercialization

ii. Professional productivity and commercialization perspective

iii. Factors that could enhance research commercialization

iv. Problems and initiatives related to manpower

v. Initiatives related to the marketing strategy

Figure 6 shows the research model that was designed to suit this study on the impediment in research commercialization tailored to the academic setting. 


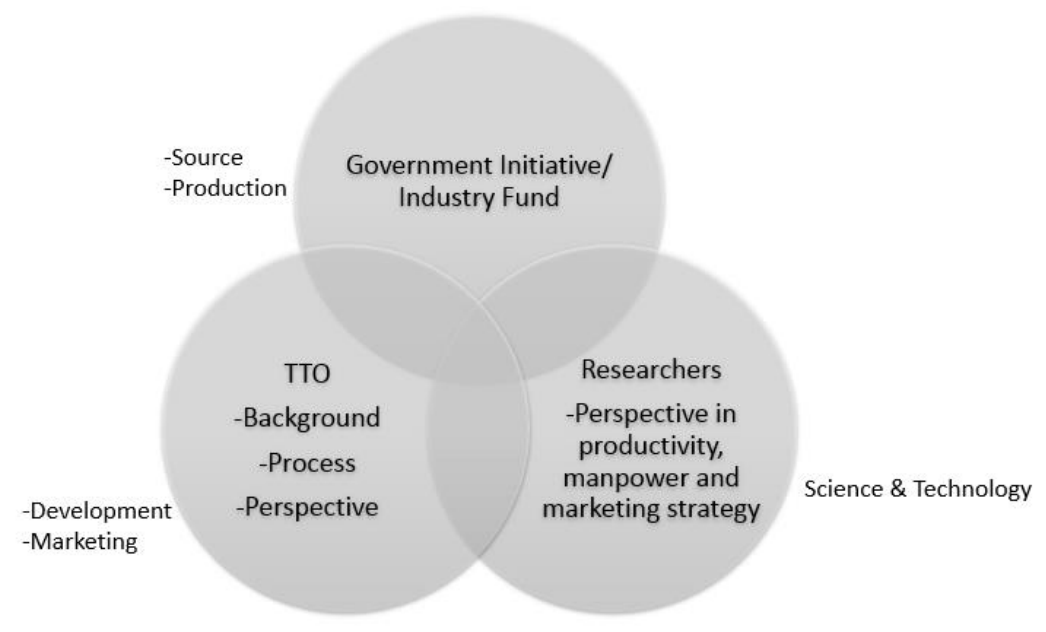

Figure 6: Research model designed to develop instruments for research commercialization.

We created a research model to serve as a guide for university-industry and technology transfer offices, as well as the government, in order to improve collaboration and research within academic settings in Malaysia. It is worth noting that the implementation of this approach has the potential to increase communication between all sectors, including the ministry of higher education. The relationship between these three parties will have a substantial impact on the research study's objectives. The role of government and industry in fostering good university-industry partnership is critical. The Malaysian government provides not just rules and regulations, but also grants. Technology transfer office is responsible to give a guidance for research staff regarding how to develop new research study according to some protocol whether for intellectual property (IP), license, pattern, benchmark and copyright. Research staff is being a part of science and technology sectors. Researchers must know what their perspective in productivity, manpower and marketing strategy for their research study is to ensure successful product commercialization.

\subsection{Discussion}

Several researchers deploy qualitative data collection to research on commercialization through interviews of several researcher. This study designed a quantifiable survey and indepth questionnaire that is relevant to the research commercialization setting to reach researchers and Technology Transfer Office personnel.

The following research model was designed to include factors reviewing the impediment factors in commercialization of an academic institution.

\subsection{Developing Instrument for TTO Input}

In the university, various options for research commercialization are accessible. Internal, quasi-internal, and externalisation approaches were chosen by several institutions (Markman et al., 2008). Technology Transfer Office is the key to a successful commercialization. The unit is required to have traits of business acumen in order to guide 
and assist academician to seize an opportunity for commercialization, regardless as basic research, applied research or translational research.

The questionnaire is designed based on literatures on the function of TTO and to suit with the setting of the TTO units in academic institution.

Questionnaire for Technology Transfer Office (TTO)

\section{Background}

\begin{tabular}{|c|c|}
\hline No. & Questions \\
\hline 1 & What is the role of university technology transfer in the innovation process? \\
\hline 2 & $\begin{array}{l}\text { How many units and researchers were successful in inventions in the last three } \\
\text { years, from } 2017 \text { to } 2019 \text { ? }\end{array}$ \\
\hline 3 & $\begin{array}{l}\text { What resources does the TTO provide in terms of quantity and quality to help in } \\
\text { commercialization? }\end{array}$ \\
\hline 4 & How many patents are issued as a result of disclosures? \\
\hline 5 & $\begin{array}{l}\text { What are some examples of Sponsored Research Agreements (SRAs) formed with } \\
\text { the TTO's help? }\end{array}$ \\
\hline 6 & $\begin{array}{l}\text { Is the university in possession of venture capital funds that could be used to fund a } \\
\text { qualified start-up? }\end{array}$ \\
\hline 7 & $\begin{array}{l}\text { What policies does the university have in place when it comes to commercialization } \\
\text { of inventions and conflicts of interest? }\end{array}$ \\
\hline
\end{tabular}

\section{Process}

\begin{tabular}{|c|c|}
\hline No. & Questions \\
\hline 1 & $\begin{array}{l}\text { What factors that can lead to success and failure in the process of } \\
\text { commercialization? }\end{array}$ \\
\hline 2 & What is the Process of Technology Commercialization before start up? \\
\hline 3 & $\begin{array}{l}\text { Models of University Technology Commercialization channels and their problems } \\
\text { used in pre-incubating process? }\end{array}$ \\
\hline 4 & $\begin{array}{l}\text { How do universities provide incentives to companies to develop university } \\
\text { technologies into commercial products? }\end{array}$ \\
\hline 5 & How does the TTO handle innovation disclosures? \\
\hline 6 & How does the TTO encourage community innovation? \\
\hline 7 & What is the TTO's strategy for venture capital? \\
\hline 8 & $\begin{array}{l}\text { When it comes to royalties, how does the institution usually distribute them to } \\
\text { inventors? }\end{array}$ \\
\hline 9 & What factors do you consider while deciding which inventions to patent? \\
\hline 10 & $\begin{array}{l}\text { When researchers } \bullet \text { Enter employment with IP and licences developed at another } \\
\text { university } \bullet \text { Leave the university for either other academic environments or } \\
\text { commercial employment, how has the university generally managed IP rights and } \\
\text { licences? }\end{array}$ \\
\hline
\end{tabular}


Perspective

\begin{tabular}{cl}
\hline No. & \multicolumn{1}{c}{ Questions } \\
\hline 1 & $\begin{array}{l}\text { What are the strategies UTP utilize to promote the dissemination and utilization of } \\
\text { discoveries made in research on campus? }\end{array}$ \\
2 & $\begin{array}{l}\text { Why the process Imagining stage to the Incubating stage have challenge to the } \\
\text { researchers? }\end{array}$ \\
3 & $\begin{array}{l}\text { Do patents create barriers that hinder innovation and research? } \\
4\end{array}$ \\
5 & $\begin{array}{l}\text { What areas (products, processes, and research) has the TTO been most active in } \\
\text { What are the inventor's responsibilities, according to the TTO, in terms of obtaining } \\
\text { commercialization funds? }\end{array}$ \\
6 & $\begin{array}{l}\text { What kind of experience does the TTO have with software patents, copyrights, } \\
\text { trademarks, and licences? }\end{array}$ \\
\hline
\end{tabular}

TTO resources and capability have been recognised as one of the elements affecting technology transfer in Malaysian universities in some research. The goal of interviewing TTO personnel is to learn more about the experienced TTO team's research commercialization process with past researchers. The TTO team's responsibilities include managing intellectual property (IP) applications, establishing spin-offs, licencing, pattern, copyrights, marketing the technology, and guiding researchers through the technology transfer process. Technology transfer office usually will advise researchers to find suitable partner industry and research fund to commercialize their product into the market section. Some issues pointed out during the interview will be used for future improvement.

\subsection{Developing Instrument for Researchers Input}

The instrument that will be deployed to the researchers is a survey carefully designed through extensive literature studies. The survey statements and questions are checked to suit with the environment of the University.

The profile of the researcher will be anonymous, the information required will only be on the type of research and the academic position rank at their workplace. Translational, Applied and Basic research study have different research outcome. The nature of the research will be mapped to the impediment factors in commercializing their research output.

The academic position rank in the institute are listed as Professor Dr., Associate Professor Dr., Associate Professor, Senior Lecturer, Lecturer and Postdoctoral researcher. This is to correlate the experience in commercialization by academic position.

a) Impediments to research commercialization

\begin{tabular}{llccc}
\hline $\begin{array}{l}\text { Strongly } \\
\text { Disagree }\end{array}$ & Disagree & Neutral & Agree & $\begin{array}{l}\text { Strongly } \\
\text { Agree }\end{array}$ \\
\hline
\end{tabular}

There are no impediments to

commercializing research at

Universiti Teknologi

PETRONAS.

There is unwanted risk

associated with research

commercialization.

I lack the expendable time. 
There is excessive expense

There is a lack of inventors

There is a lack of infrastructure

including facilities and staff to

help in the commercialization

process.

Unsupportive University

policies, procedure and/or

regulations.

There is a lack of industry

partners.

Limited or no commercial

application of my research

exists.

There is a lack of importance to

academic.

There is a lack of importance to

my field.

There is a lack of benefits to

society.

Lack of interest on R\&D

commercialization.

This table shows several questions for previous researchers or lecturers to share their experienced deal with some issues during their research period. This data is crucial to identify some impediments involved and make an improvement for future use commercialization process. Study the impediments in innovation play an important role to know which factors that contribute to failure among researchers. There are five factors involved in innovations activities such as cost, regulatory or policy, market, knowledge, and organisational factors that need to focus on if researchers want to get involve in product commercialization.

b) Factors that could enhance research commercialization

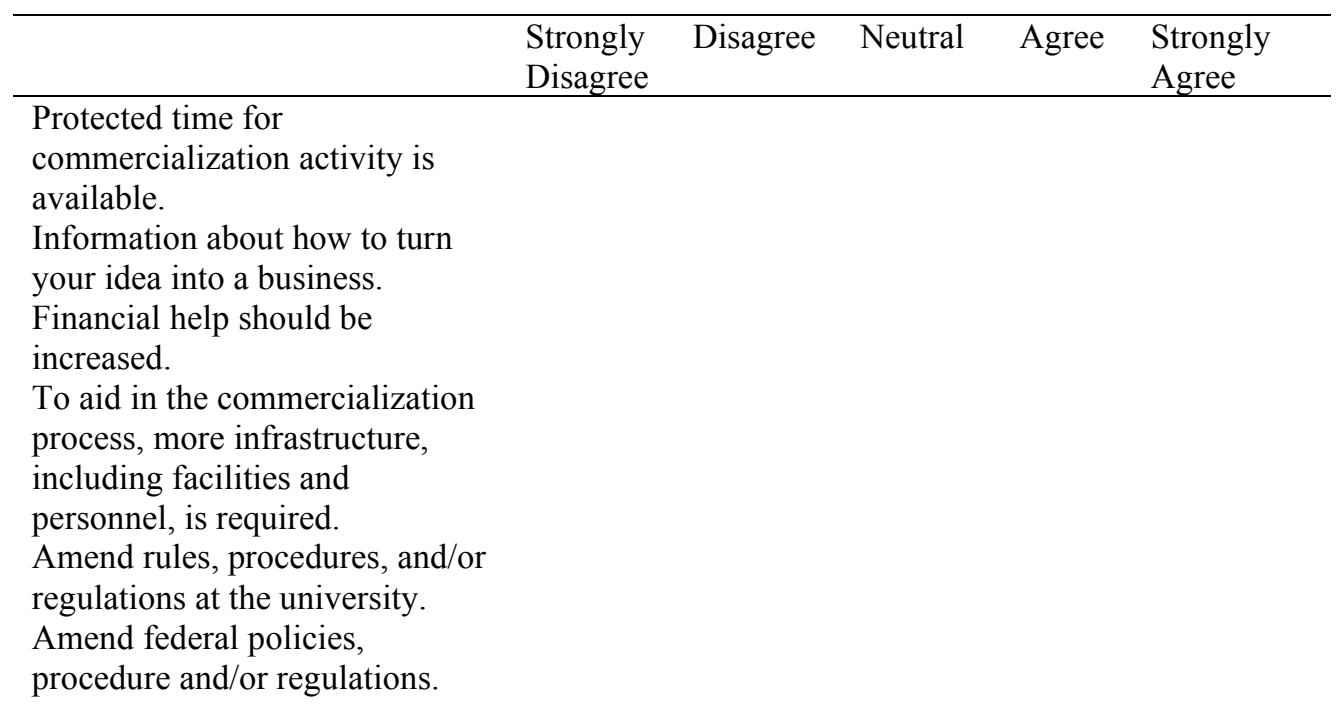


Enhances links to industry.

Academics and/or my research

field are increasingly

emphasising the importance of

research commercialization.

Greater personal benefits

including more royalty pay.

Greater societal benefits.

Nothing would help.

There are various reasons that can contribute to an increase in research commercialization among academic researchers in Malaysian universities, according to this section of the questionnaire. Most participants identified a lack of research funding as a major obstacle, which leads to a shortage of resources, such as well-equipped research and development laboratories (Azman et al., 2019). As a result, the government and other funding organisations have offered a variety of incentives to encourage universities and researchers to participate in product commercialization. To avoid failure, researchers should be aware of the processes, policies, and regulations in place prior to beginning the commercialization process. Academia and research workers need to collect data and analyse it for commercialization activities at the right time and in the right place. Time to commercialise, link industry, government policy, IP laws, and guidelines for research technology transfer are all important aspects for successful commercialization (Sharif et al., 2018).

c) Problems and initiatives related to manpower

\begin{tabular}{|c|c|c|c|c|c|}
\hline & $\begin{array}{l}\text { Strongly } \\
\text { Disagree }\end{array}$ & Disagree & Neutral & Agree & $\begin{array}{l}\text { Strongly } \\
\text { Agree }\end{array}$ \\
\hline $\begin{array}{l}\text { Lack of qualified staff or } \\
\text { skilled manpower limits the } \\
\text { potential to produce a larger } \\
\text { scale of production. } \\
\text { Lack of flexibility with } \\
\text { respect to researchers } \\
\text { mobility. } \\
\text { Overlapping responsibilities } \\
\text { and roles from spin-off } \\
\text { companies that affect quality } \\
\text { of work, products, and } \\
\text { performance. } \\
\text { University should establish } \\
\text { one stop centre to facilitate } \\
\text { researchers. } \\
\text { Permanent, skilled, and } \\
\text { competent staff must be } \\
\text { appointed to help for } \\
\text { commercialization. }\end{array}$ & & & & & \\
\hline
\end{tabular}


Majority of researchers in research institution have problems that related to the manpower while conducting research study. Lack of qualified staff give result in low efficiency of commercialization management structure systems that is significant in the economic development and growth. To achieve a successful commercialization process at the institution, they should develop a single location to assist research work. Facilities and qualified personnel are required to sustain commercialization activities within the institution, which may include the establishment of a research management centre (RMC) or a technology transfer office (TTO) to aid and encourage commercialization. Furthermore, a competent, professional, and permanent staff must be assigned to the centre in order to supervise business, legal, and technical aspects of the commercialization process for academic researchers (Rahim et al., 2019).

d) Initiative related to marketing strategy

\begin{tabular}{|c|c|c|c|c|c|}
\hline & $\begin{array}{l}\text { Strongly } \\
\text { Disagree }\end{array}$ & Disagree & Neutral & Agree & Strongly Agree \\
\hline $\begin{array}{l}\text { Realign research } \\
\text { commercialization and } \\
\text { product (package and } \\
\text { promotion). } \\
\text { Innovation development } \\
\text { centre and effective } \\
\text { support group to conduct } \\
\text { product development. } \\
\text { Market analysis should be } \\
\text { given a priority at the } \\
\text { beginning (market } \\
\text { potential, market needs } \\
\text { and research product). }\end{array}$ & & & & & \\
\hline
\end{tabular}

According to (Norain at al., 2019), marketing strategy is essential for academic researchers to determine the commercialisation activities. They need to know the market potential for the product such as good quality, reasonable price, their features uniqueness, and commercial value before entering viable market. Currently, industrial sector more prefer to be a consumer for a market ready product from the university rather than as manufacturer.

e) Professional productivity and commercialization perspective

\begin{tabular}{l}
\hline \\
\hline Do you feel that your research results are sufficiently
\end{tabular}


Do you think your research field places an emphasis on research commercialization?

Do your research project give benefits to community, industries and government agencies?

This table represents the views of researchers who expect to continue their research in the future. Even if the concepts were wonderful to enter the feasible market based on current demands, the majority of researchers (Baglieri et al., 2018) indicated that they intend to commercialise their product in the future if there are no links with the industry to ascertain their needs. Moreover, funding issues is crucial for academic setting to proceed their product commercialization process. Due the lack of funding by government and others financial institution, researchers may have problems to commercial their product. Good evaluation from the TTO office plays an important role to support their ideas and give explanation regarding policy and regulations for the commercialization journey (Miller et al., 2018).

\subsection{Conclusion}

This paper reviews factor that lead to the success of research commercialization for researchers. Studies on funding, knowledge, regulatory factors/public policy, market factor and organizational is very crucial in the start-ups research process for a successful innovation commercialization performance in universities. The responsibilities and the importance of TTO is deemed crucial to secure success in commercializing the research outputs by the researchers. Tackling impediment factors to motivate researchers, will lead to sustainable growth in commercialization. Engagement in a market-driven research approach, in-line with the recognition of innovation, act as catalyst of wealth creation for economic, social and cultural developments.

\section{Acknowledgements}

The authors are thankful with the support from Institute of Hydrocarbon Recovery (IHR) Director, AP Dr Syahrir Ridha, and fund from International Collaborative Research Fund (ICRF) Grant No. 015ME0-115 and Universitas Islam Indonesia (UII) for their support to the project.

\section{References}

1. Abdul Hamid, N., \& Abd Rahman, A. (2014). A systematic literature review on the success factor of innovation commercialization performance.

2. Abdul Razak, A., \& Murray, P. A. (2017). Innovation strategies for successful commercialisation in public universities. International Journal of Innovation Science, 9(3), 296-314.

3. Ajagbe, M. A., Ismail, K., Isiavwe, D. T., \& Ogbari, M. I. (2015). Barriers to Technological and non-Technological Innovation Activities in Malaysia. European Journal of Business and Management, 13.

4. Ali, R., Leman, A. M., Sunar, N. M., \& Ahmad, A. N. (2017). Issues Related to Low Commercialisation Rates of the University's Research and Development (R\&D) Products: Industrial Perspective. Advanced Science Letters, 23(11), 10616-10620. 
5. Arenas, .J J., \& González, D. (2018). Technology transfer models and elements in the University-Industry collaboration. Administrative sciences, 8(2), 19.

6. Azman, N., Sirat, M., Pang, V., Lai, Y. M., Govindasamy, A. R., \& Din, W. A. (2019). Promoting university-industry collaboration in Malaysia: Stakeholders' perspectives on expectations and impediments. Journal of Higher Education Policy and Management, 41(1), 86-103.

7. Baglieri, D., Baldi, F., \& Tucci, C. L. (2018). University technology transfer office business models: One size does not fit all. Technovation, 76, 51-63.

8. Banal-Estañol, A., \& Seldeslachts, J. (2011). Merger failures. Journal of Economics \& Management Strategy, 20(2), 589-624.

9. Boal, K. B. and Hooijberg, R. (2000), "Strategic leadership research: Moving on", The Leadership Quarterly, Vol. 11 No. 4, pp. 515-49.

10. Charles, D. (2003), 'Universities and Territorial Development: Reshaping the Regional Role of UK Universities, 'Local Economy, 18: 1, pp. 7-20.

11. Christensen,C. (1997) Innovators Dilemma. Boston: Harvard Business School Press.

12. Collier, A., Gray, B. J. and Ahn, M. J. (2011), "Enablers and barriers to university and high technology SME partnerships", Small Enterprise Research, Vol. 18 No. 1, pp. 2-18.

13. Dai, Y. (2007). Patent or publish? -University researcher's choice between traditional and commercial research outcomes. Syracuse University.

14. Datta, A., Jessup, L., \& Reed, R. (2011). Corporate Reputation and the Commercialization of Innovation: Does Reputation Match Reality, and Does Innovation Matter? Technology and Investment, 02(04), 256-272.

15. Dasgupta, M., Gupta, R. K., \& Sahay, A. (2011). Linking Technological Innovation, Technology Strategy and Organizational Factors: A Review. Global Business Review, 12(2), 257-277.

16. Determinant Factors for Commercialising Research Products in Malaysian Public Universities. (2). International Journal of Innovative Technology and Exploring Engineering, 8(6S4), 780-787.

17. Ee Shiang, L., \& Nagaraj, S. (2011). Impediments to innovation: Evidence from Malaysian manufacturing firms. Asia Pacific Business Review, 17(2), 209-223.

18. Farley, A. \& Abd Rahman Ahmad. (2013). Federal government funding reforms: issues and challenges facing Malaysian public universities. International Journal of Asian Social Science, 3(1); 282-298.

19. Fletcher, A. C., \& Bourne, P. E. (2012). Ten simple rules to commercialize scientific research. PLoS computational biology, 8(9).

20. Gunasekara, C. (2004), 'The Third Role of Australian Universities in Human Capital Formation,' Journal of Higher Education Policy and Management, 26: 3, pp. 329-343.

21. Hartono, A., \& Kusumawardhani, R. (2019). Innovation Barriers and Their Impact on Innovation: Evidence from Indonesian Manufacturing Firms. Global Business Review, 20(5), 1196-1213.

22. Hamid, N. A., \& Rahman, A. A. (2014, May). A systematic literature review on the success factor of innovation commercialization performance. In 2014 International Symposium on Technology Management and Emerging Technologies (pp. 199-204). IEEE.

23. Harmancioglu, N., Grinstein, A., \& Goldman, A. (2010). Innovation and performance outcomes of market information collection efforts: The role of top management team involvement. International Journal of Research in Marketing, 27(1), 33-43. 
24. Heng, L. H., Rasli, A. M., \& Senin, A. A. (2012). Knowledge Determinant in University Commercialization: A Case Study of Malaysia Public University. Procedia - Social and Behavioral Sciences, 40, 251-257.

25. Hertzfeld, H. R., Link, A. N., \& Vonortas, N. S. (2006). Intellectual property protection mechanisms in research partnerships. Research Policy, 35(6), 825-838.

26. Ibata-Arens, K. (2008). Comparing National Innovation Systems in Japan and the United States: Push, Pull, Drag and Jump Factors in the Development of New Technology. Asia Pacific Business Review, 14(3), 315-338.

27. Iammarino, S., Sanna-Randaccio, F., \& Savona, M. (2007). The perception of obstacles to innovation. Multinational and domestic firms in Italy. Office of Economic Theory and Application.

28. Ismail, K., \& Ajagbe, M. A. (2013). The Roles of Government in the Commercialization of Technology Based Firms. 8.

29. Ismail, N., Nor M. J. M., \& Sidek, S. (2017). Challenges for Research Product Commercialisation: A Case of Malaysian Academic Researchers. Journal of Engineering and Applied Sciences, 12(6), 1543-1550.

30. Ismail, N., Sidek, S., \& Nor, M. J. M. (2015). Collaboration Between Academic and Industry Partner for a Successful Research Products Commercialisation in Malaysia. 4.

31. Ismail, N., Sidek, S., \& Nor, M. J. M. (2018). Determinant factors for effective collaboration between university and industry in commercialising research products in Malaysia. In 27th International Business Information Management Association Conference-Innovation Management and Education Excellence Vision 2020: From Regional Development Sustainability to Global Economic Growth, IBIMA 2016 (pp. 2384-2394). International Business Information Management Association, IBIMA.

32. Jewels, T., Al-Rawshdi, A., Abusharekh, R. N. and Shamisi, A. S. (2011), Organisational Culture and Its Effects on Innovation within ERP Systems in Open Innovation in Firms and Public Administrations: Technologies for Value Creation, IGI Global, Pennsylvania, United States.

33. Kamaruddin, N. K., \& Samsuddin, A. (2013). A case study of $R \& D$ technology commercialisation: challenges, issues, and the way forward.

34. Khademi, T., \& Ismail, K. (2013). Commercialization Success Factors of University Research Output. Jurnal Teknologi, 64(3).

35. Lee, K.-J., Ohta, T., \& Kakehi, K. (2010). Formal boundary spanning by industry liaison offices and the changing pattern of university-industry cooperative research: The case of the University of Tokyo. Technology Analysis \& Strategic Management, 22(2), 189-206.

36. Markman GD, Gianiodis PT, Phan PH and Balkin DB (2005). Innovation Speed: Transfering University Technology to Market. Res. Policy, (34):1058-1075.

37. Markman, G. D., Siegel, D. S., \& Wright, M. (2008). Research and Technology Commercialization. Journal of Management Studies, 45(8), 1401-1423.

38. MASTIC. 2008. National Survey for research and Development, Putrajaya, Malaysia. Malaysian Science and Technology Information Centre.

39. Markman, G. D., Siegel, D. S., \& Wright, M. (2008). Research and technology commercialization. Journal of Management Studies, 45(8), 1401-1423.

40. Manap, A., Ismail, N., \& Sidek, S. (2017). The roles of technology transfer offices to facilitate intellectual property commercialization in the university: Issues and challenges. The Social Sciences, 12(6), 919-924. 
41. Miller, K., McAdam, R., \& McAdam, M. (2018). A systematic literature review of university technology transfer from a quadruple helix perspective: toward a research agenda. R\&D Management, 48(1), 7-24.

42. Mohd-Azmi, M. L., Jesse, F. F. A., Sarah, S. A., Roslan, S., Zuraidah, A., \& Hambali, I. U. (2016). Transforming Agriculture Research into Commercialisation: Experience of Universiti Putra Malaysia. Pertanika Journal of Social Sciences \& Humanities, 24(3).

43. Mora-Valentin, E. M., Montoro-Sanchez, A., \& Guerras-Martin, L. A. (2004). Determining factors in the success of $R \& D$ cooperative agreements between firms and research organizations. Research Policy, 33(1), 17-40.

44. Nor, M., \& Jailani, M. (2014). Determinants for a Successful Commercialisation of Technology Innovation from Malaysian Universities. 1, 10.

45. Norain,I \& Safiah,S. (2019).Determinant Factors for Commercialising Research Products in Malaysian Public Universities 2278-3075.

46. Rahim, N. A., Mohamed, Z. B., Amrin, A., Masrom, M., \& Azmeela, S. Conceptualization And Measurement Of University Technology Transfer Office Efficiency As A Formative Construct

47. Sanberg, P. R., Gharib, M., Harker, P. T., Kaler, E. W., Marchase, R. B., Sands, T. D., Arshadi, N., \& Sarkar, S. (2014). Changing the academic culture: Valuing patents and commercialization toward tenure and career advancement. Proceedings of the National Academy of Sciences, 111(18), 6542-6547.

48. Siegel, D. S., \& Wright, M. (2007). Intellectual property: the assessment. Oxford Review of Economic Policy, 23(4), 529-540.

49. Sohail A.S. (1997). A longitudinal study of planning and implementation of advanced manufacturing technologies.

50. Stumpf, S. A., \& Mullen, T. P. (1991). Strategic leadership: concepts, skills, style and process. Development, 10(1), 1-991.

51. International Journal of Computer Integrated Manufacturing, 10(1-4), 281-295.

52. Sutopo, W., \& Astuti, R. W. (2017). The Schemes Funding Analysis for Technology Commercialization: A Case Study. 10

53. Sharif, S. M., Ahamat, A., Abdullah, M. M., Jabar, J., \& Bakri, M. H. (2018). University Intellectual Property Commercialization: A Critical Review of Literature. Turkish Online Journal of Design Art and Communication, 8(SEPT), 874-886.

54. T. D., Arshadi, N., \& Sarkar, S. (2014). Changing the academic culture: Valuing patents and commercialization toward tenure and career advancement. Proceedings of the National Academy of Sciences, 111(18), 6542-6547.

55. Thursby, J. G., Jensen, R., \& Thursby, M. C. (2001). Objectives, characteristics, and outcomes of university licensing: A survey of major US universities. The journal of Technology transfer, 26(1-2), 59-72.

56. Wood, M. S. (2011). A process model of academic entrepreneurship. Business Horizons, 54(2), 153-161. 